encouraged to speak, but in cases of bad speakers further improvemrent was secured by sending them to a roice trainer. The voice was always sufficient for the ordinary purposes of life: schoolmasters had been able to continue their profession, and other's could make public speeches. But all the patients had not been kept silent for these first three weeks, and he thought that by earlier resumption of rocal use there hat been better compensatory results, and not that tendency to contraction which had been observed in two of the most silent cases. He now thought a week's silence was sufficient. If patients applied early with epithelioma limited to a vocal cord the death-rate should be nil, the restoration of voice satisfactory, and the cure lasting.

Surgeon-General Briketr, C.A.M.C., agreed that fixation of the cord was no invariable sign. All must have seen cases when it was absent.

Mr. WILFRED 'TrotTh said that his practical experience was contined to conditions extra-laryngeal. He had been removing the ala of the thyroid cartilage for ten years for another reason-namely, to obtain access to the upper part of the larynx, and consequently had removed the ala more completely, including both cornua. He had probably removed the whole ala fifty times, and there was no evidence that it interfered with the recovery of the patient's voice. It was a harmless and very useful procedure. He had never ligatured or clamped the thyroid isthmus, and no evil results had followed. An important reason for dividing the isthmus was that if the tracheotomy tube had to be removed the isthmus could not descend over the opening and hinder its replacement. He lrail known lives sacrificed in this way by leaving the istlimus intact.

Irr. W. Hru mentioned a case in which fatal lraemorwhage had occurred, as evidence of the value of retention of the tracheatomy tube and plugging temporarily, for by this means death might have been avoided.

Mr. Herbert' 'IrLLEY had operated upon twenty-two such cases. He thought that this kind of cancer might form a basis frou which some clear ideas might be evolved on the infectivity of the disease. In this respect cases in which growth recurred ten, twelve, or mone years after aperation were interesting. He doubted whether " recur rence" was the proper term, and queried whether an imunnization took place, and that the so-called "recurrence" followed when that immunization wore off.

Mr. IRwI Moore advised that the tracheotomy tube should be left in situ for a few hours if neither the surgeon nor a dopendable substitute were within imme diate call. There was particular risk in leaving a patient with no tube after low tracheotomy. 'The results of operation were so good chiefly because the operation was done early and the diagnosis was established. He hoped for more co-operation with the general physician in cases of persistent hoar'seness.

Mr. C. McMaron offered the following suggestions for ve-eilucation of the voice in these cases :

1. Develop the sterno-thyroid and sterno-hyoid muscles, and lieep the laryni low. Use a tongue depressor to help to accomplish the descent of the larrnx.

2. Make the patient speak as little as possible until a tleep pitch of voice is establisher.

3. Let the breathing movement be inferior lateral costal, with a small but definite expansion, and let the motive powe of the voice be the powerful contraction of the abdominal muscles.

4. When the larynx is established in its low position instruc the patient that voice gets its chief resonance in the head and chest, and that the throat is a conduit pipe between them, and must be entirely unconstricted; and also that fiee lip nove unent increases oral resonance. If further vocal treatinent is necesury the resomator positious of rowel sounds aul clearnews of articulation generally should be taught.

A really useful voice can be anticipated in practically all cases.

Mr. Migar SWIFT, K.C., at the request of the Minister of Pensions, has become president of the Officers' Appeal Boara; the other menibers of the Board are Dr. Norman Wrove, president of the Royal Collese of Physicians of Iundon; Sir Alfred Pearee Gauld, K.C.V.O.; and Captain Albert Simith, M.P. An officer whose claim for retired pay from the Ministry of Pensions has been refused on the from the Ministry of Pensions has been refused on the rated by, military service, may ask the Ministry to refer lais clain to the Appeal Board, which meets at intervals as the cascs to be dealt with require.

\section{THE BRIDGE-HEAD.}

SIR ANDREW MACPHAIL.

The end has come. This Ambulance, which was in Rest at Boolezele, ${ }^{1}$ which spent a Wet Night in the forest of Eperlecques," and did a Day's Work on Vimy Ridge, ${ }^{3}$ is now in the Cologne Bridge-head at Sieghurg, trans flumen Rhenum.

This most mobile of all military units has reacherl the limit of its forward wanderings, and is now at ease in a noble house in a pretty town in a peaceful and pleasant country. With work it has nothing to do. There are a few cases of influenza to be cared for, but the great days are gone for ever. In these two divisions of the Canadian corps, numbering sixty thousand men, there were only eleven deaths during the five weeks of occupation. The medical officers have ample leisure to brood over the past, and compare their present magnificence with the sordici surroundings, the squalid discomfort, and the poignant tragedy of the four preceding years and winters.

This Ambulance mobilized in Montreal, November I4th, I9I4. It came overseas in April, I9 I 5, and went to France in the following September. The normal establishment of officers is ten, and of the original personnel only two remain. It has had its losses. The colonel was killed at Courcelette; a captain was killed at Amiens; the quartermaster at Arras. Also, it has had due share of honours. To these officers wore awarded four D.S.O.'s, one additional bar, foul' military crosses, and one knighthood. Of the other: ranks one half remains, and one third of the horses are yet in service.

The Rhine was crossed on Iecember I 3 th. The crossing was a ceremonial, and one who rides in ceremony sees nothing but his hor'se's ears, save for the moment when he turns "eyes right," and then he sees only the saluting officer. But it must have been to the observers a great show of power. From eight in the morning until four in the afternoon the, troops were crossing in columns of route, ten yards between battalions, fifty between brigades. The troops marched without open enthusiasm, without emotion, void of passion, with no sign of imagination, without any apparent pride, but with the slow relentlessness of a glacier, with the inevitable power of a geological movement, file after file of fours with bayonets fixed, wagon alter wagon, gun after gun, loriy after lorry-no haste, no confusion, no halts. Each column passed the saluting point to the ninute, every horse and erery man in his appointed place: and this alter a march of nine days at twenty miles a day with rations none too abundant, for the rail-head was left perilously far behind.

A bridge-head has little to do with a bridge. It is an area as large as an English county. If one point of a compass be placed upon Cologne and the other upon Bonn, which is twenty miles to the south, and the compass be turned eastivard in a great halfcircle and back to the river arrain at the north, the line will fall far within the broken hills which border the Rhine valley. The line itself follows a good contour, and a commanding position is not sacrificed to topographical exactness. The army believes in a margin of safety.

The bridge-head is a country of wood, copse, orchard, farm, heath, dry and wet meadows, fern, moor, moss, and water flowing in rivers, rushing in streams, still in pools or stagnant in the ditches. The main roads are paved with stone or cernent blocks.

1 HAITISH M RDroat, JodrNaL, September 1st. 1917.

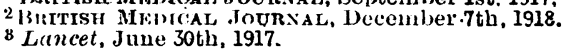


Other roads are well metalled, or made from the soil, but good. Then there are farm roads from which one can walk up the hills by bridle-paths.

The spectacle of real interest in the bridge-head is the Germans themselves. It seems incredible that one can see enough of them. For four years they were as elusive as ground-hogs; and the belief grew that there were none, that they had all gone home; but this belief could be quickly dispelled by lifting one's head above the parapet. An occasional prisoner and on certain days of the year whole companies marching down, that was all one saw of the Germans; but here one may stand all day to the eye's content. They throng the streets, stream across the bridges, and inhabit the villages; but it is in the opera house at Cologne they are seen in their native haunt.

In the mass the Prussian is singularly true to type. As they sit in rows they are all the same, with sloping shoulders, hard, lean, implacable faces, dull as Mongolians, and without much head behind their cars. At regular intervals in the rows the face of a Jew looks intimate ard almost friendly. They are all dressed in black, and the absence of colour from the women's garb gives an impression of melancholy and gloom. The women look like overgrown girls, their dress conventional, but short at the bottom and short at the top. The eyes of men and women alike are holden from seeing us. We are to them as ghosts and shadows. Their mien is one of cold neutrality. They do not stare, and they do not turn aside. Never before was witnessed so strict and formal a politeness; but a world without a smile is a cheerless world.

The opera is done with full pomp, and the house is always crowded. The performance begins at such an hour as will bring it to an end before eight, as civilians must be in their homes by nine. The hour was originally seven, but that interfered with business. One might wish to buy something, and the time was cinanged for our own convenience. For the first day or two it was a rule that officer's must be saluted by civilians; but returnirig the salutes became so irksome that the practice was abolisbed.

The Germans think we do the occupation business very badly. Their method in Belgium and France was in their eyes the proper way. They are disappointed. Even a photographer who is engaged to make a group of officers will demonstrate to them in his own person what they should do to make themselves look fierce and haughty. They do not understand that a soldier may bo pleasant yet implacable, victorious without arrogance, at once merciful and just. The English are frightfully righteous, they say. They ask the meaning of it, and the only answer is that the English make war upon armies, not upon sivilians, not upon women and children.

For the benetit of those who are to write the history of the war let it be recorded that Cologne was first occupied by a Canadian subaltern of sappers. This young officer was returning from leave. At various times for four years he had been returning from leave, and the ethics of the return is to arrive at the front without delay. But in the meantime the corps may have moved to a new area." It is the business of the Railway Transport Officer to direct inquirers to their units; but the R.T.O. is the last man in the army to know where a unit is at any given moment. The permissionnaire turns his face eastward and takes to the road. He enters any train that appears to be going in that direction, and completes the journey in a chance lorry; mess-cart, or ambulance.

For four years there was a fair degree of certainty that the conveyance would not go too far. The German line from the sea to Switzerland : was an effective barries. At one station this sapper oflicer saw a train heading in the right direction. It appeared to be commodious and he went on board. It turned out to be the armistice train, and it deposited him in Cologne. He could have gone to Berlin, but his immediate concern was to rejoin his unit. When the train proceeded he was the only British officer in Cologne. In this strange circumstance he did the obvious thing. He went to ar hotel, engaged a room, and having taken possession waited until his unit arrived for his support.

The spell of the Rhine has fallen upon the troops. The river is of the proper size and speed. It is unmistakably a river and not a lake. By day its surface is yellow and finely wrinkled like the face of $a$ slow, sad old man; by night like burn shed metal it gives back the lights in shafts of red, yellow, and silver. Soldiers cross and recross. The New Zealander is there; but it is not the ruins of St. Paul's he regards. It is the Hohenzollern bridge he stands upon, a contraption of towers, turrets, battlements, and embrasures, like a thing upon the German stage. He considers the four equestrian statues, two at each end, beautifully weathered, but he finds something comical in the bronze truculence of tail, and mane, and plume. In the western background are ever the twin towers of the cathedral like saw-toothed bayonets. A sapper, who in virtue of his craft has an eye for wide impressions, found in this edifice a resemblance to an enormous man with shaggy head and hairy chest, and powerful arms, but with no loins nor legs nor guts; and he contrasted it with the church at Amiens with its single spire, which, as he said, arose like a rod of spikenard in the wilderness.

Below the bridges the barges pass, and one still bears upon its prow a miniature Christmas tree. Down stream the bridge of boats is open so that the current may have free way; for the river is in flood, and a boy is poling an improvised raft in the overflown waters. Up stream the New Bridge stretehes its three delicate spans across - a frank structure such as any rational people might build. A single aeroplane patrols slowly up and down the river: that is the only sign that a state of war still exists.

In Cologne it is even more like the old tourist days, and the music shop of $\mathrm{P}$. J. Tonger is doing its usual business. The place was comfortably filled with men, women, and a few officers, buying the scores of the opera; and they were as solemn as if buying a piece of music were a sacrament. The shop is like the library of a college, the alcoves adorned with the traditional busts. A woman was in doubt about the music she wanted, and the assistant hummed the various tunes to her. He wore a $G$ clef in gold as a scarf-pin. He sold the scores of "Tannhquser," " Lohengrin," "The Flying Dutchman," "Mignon," and "Carmen" at four to six marks apiece. Ilad he Charpentier's "Paris"? He missed the irony of the request. "I will ask my colleague," he said. Had he "Parsifal"? "I should hope so," he protested with a fervour that was almost religious.

The army is disturbed. It is the children who disturb them. Wherever one dismounts a crowd assembles, singularly devoid of beauty, as nervous as wild animals, pale to yellowness, with dull, apathetic faces; without a trace of colour in any cheek. One child was eating a piece of disgusting, black, sodden bread. A boy showed an unhealed wound following an operation for hare-lip, more repellent than the original deformity. One of the more forward asked in a negative way for chocolate- nicht Schokolade?and his companions were alarmed at his boldneso.

On Christmas Day we made our first visit to the outposts. The journey began at Deutz, which is across the river from Cologne, and ended at Lindlar, 
a good twenty miles into the north-eastern hills. The route lay by Ostheim, Heumar, Rosrath, ImmeKeppel, Hoch-Keppel, and Vellingen, at first squalid villages and then hamlets of scattered houses. Once clear of the town the road enters a planted forest of oak; spruce, fir, elm, pine-all laid out like a town. The plantings of each year could be distinguished, and they ranged from a foot in height to well grown trees fit at least for the timbering of mines.

Once through the forest the Agger was seen tumbling down from the hills, and a branch of the main stream served as an upward guide. Snow lay upon the ground as we rose, but in the river bottom on the right the grass was green along the narrow ditches that drained the land. Groups of people, mostly old : women, young women, children, and old men, all in decent black, were on the way from church, following paths across the hills, and they would reply cheerfully to a "Merry Christmas." Although there is a rule against "fraternizing," there was no harm in saying that much.

After travelling 25 miles in a north-easterly rirection we came to a sign which indicated that we had reached the limits of the bridge-head. There was a fire of sticks in the road. A few ground-sheets spread over a frame formed a shelter. Two boys were standing by with their hands in their greatcoat pockets. They looked very cheerless. One was tall; the other was short; he had a cast in his eye. His name was Cooper. This was the army of occupation at least, this was all we saw. But we knew, and the Germans knew, that men and guns beyond belief were concealed in farms in the folds of the hills. We passed on into the neutral zone which extends ro kilometres further, and turned about at Lindlar. Civilians were going and coming, unheeded by the sentries. Although they allowed that they would stop any "suspicious characters," they did not explain the grounds on which they would "suspect" a person.

On the return journey we stopped and smoked a cigarette in a little wood on the hillside. It was free of snow, and the red needles of the fir lay clean upon the ground as in the woods at Orwell where "Gipsy" lies buried. In other places we walked on moss deep to ones spurs. A few woodmen were at work, and women were carrying off branches for their warmth. A thin blue smoke went up from a clearing. Logs were piled with scrupulous exactness against the needs of war. Something happened. There let them lie. It was all like : regarding the work of men who are already dead.

At Imme-Keppel we called at a roadside house for rest and warmth. There was a commodious room on the right of the hall. It contained a table, a bench, a few chairs, and an open cupboard with glasses and bottles. On the wall were homely pictures-an old woman sitting in a high chair with a soldier kneeling to receive her blessing ; a placid river; and a Christmas scene with the legend, "Come, Herr Jesus, and sit with us." We warmed ourselres, had a hot drink, which the woman called coffee, and a glass of "alcohol-free" stuff with a neighbour who came in.

This man had been on the Russian front fal east of Riga, and we had much talk with him. He had a way of saying "Yes," which meant, "Yes, we made a mistake. We were led astray. But there it is. What is to be done? I do not know. See what you can do to clear away the mess." Also, he was sorry for us: He was done with war. We were far from our homes. Our job was not finished. We were "sent." We could do no otherwise. The sum of his reasoning was In Russia there are good people and bad people; in England there are good people and bad people; in Germany there are good people and bad people.
The goat in the Greek verse gnawed the vine to the root; but the vine was quite sure it would yield grapes for wine to be used when the goat lay dead on the altar. The British Empire is that vine, and the German is the goat. $\mathrm{He}$ is shattered for ever. $\mathrm{He}$ is a dispersed people. The dispersion began even before the war: that is the meaning of his penetration into other lands. His empire was a fabricated thing made by hands as by one who thought to add a cubit to his stature. The fabric has come to the ground and can never be rebuilt. The German must have a mechanism for everything, and his machine has broken down. In that is the history of Germany, and the meaning of the war.

If he would draw a curtain, he must have a string and pulley. If be would lift his blind, he must have a crank and a cogged wheel. In the mess-room of this house is a peristyle against the wall like a mantelpiece. It conceals a radiator. On the floor is a grate.filled with pieces of wood nailed together. Below this wood are electric lights covered with red paper, and underneath the grate is a piece of metal to protect the floor from the imaginary heat. There is also a sheet of stamped bronze to conduct the smoke that has no existence. The contraption is to him a fireplace, and to his mind it is much better, more "efficient," than the English fireplace, which is made of stone, and burns fuel directly. He built of wood, hay, straw, stubble, and thought it stone. The world to him was a stage, and the false was the true. His whole fabric was a tower of Babel; his stones brick, slime for mortar. The Germans now look upon us not as masters, but as saviours from themselves.

January 7 th, 19r9. A train left Cologne at 5 a.m., and at sunrise I awoke, the sun looking as it looked in Flanders, shining through the vellow mist acros: the level plain. Past Eschwielorhof the country became sparse and rough. White birches and youns pines grew above the ledges of rock. After Aachen a tunnel with flaring lights; then red hills, and smoky clouds in a pale blue sky; houses on the short hillsides. Hergenrath at 9.30 ; a wide horizon upon the hills: woods broken by red quarry faces; brawling streams; red roofs, white spires; and square towers; a difficult country; one sees why the Germans preferred Belgium for their march. The journey brought us past Herbersthal, Verviers, Ensival, Papinster, Gafontaine, Nessonvaux, Trooz, Heime, leaving Liége some miles to the north. Through low hills and green valleys; at Ensival a river, probably tho Vesdre, was crossed; then the Meuse was reached. From Huy to Namur the train followed this noble river up a rich, green valley with bold cliffs on either. hand, showing tilted benches of rock. A man was ploughing with oxen, and the meadows were white with sheep. Namur was reached at 3.30 ; then we followed the pretty Sambre, a gentle stream, until the valley widened out to a pleasant countryside. Charleroi was reached at 7.30, and we harl dinner in the canteen, a gross affair.

January 8th, 1919. Awoke upon a sunless day. A windmill was in sight. We must be east of Mons or west of Arras. We were at Somain near Douai. We had made little progress in the night, and were now due at Boulogne. Soon we came into the area of roofless houses and blown bridges. There was the usual acrid smell in the air. The shell holes are quite grown with grass, but no single point arises in the desolation. It is all a shambles, a slaughterhouse, squalid as a shack wherein murder had been done. In the course of the day we passed the towers of Mount St. Eloi, which are against Vimy Ridge, and I looked upon a battlefield for the last time. 